\title{
Corporate Governance Disclosure in Annual Financial Reports and Company Performance - Evidence from Saudi Arabia
}

\author{
Sherif S. Elbarrad ${ }^{1,2}$ \\ ${ }^{1}$ Chair, Accounting and Finance Department at School of Business, MacEwan University, Alberta, Canada \\ ${ }^{2}$ Associate Professor of Accounting \& Auditing at Faculty of Commerce, Ain-Shams University, Cairo, Egypt \\ Correspondence: Sherif S. Elbarrad, Faculty at MacEwan University, 10700104 Ave, Edmonton, AB T5J 4S2, \\ Alberta, Canada. E-mail: elbarrads@macewan.ca
}

Received: September 15, 2014

Accepted: October 8, 2014

Online Published: October 25, 2014

doi:10.5539/ibr.v7n11p51

URL: http://dx.doi.org/10.5539/ibr.v7n11p51

\begin{abstract}
The aim of this research is to find the relationship between disclosure in annual reports as outlined in the corporate governance regulations imposed by the Saudi Capital Market Authority and companies' performance in Saudi Arabia. To achieve that, the corporate governance disclosure regulations are classified into four categories; Ownership structure and shareholders' rights; board of directors' information; financial information; operational information. Each category included several variables that are disclosed on the annual reports. This research is conducted on three sectors (Banking, Cement and Multi-Investment) to measure the relationship between those variables and company performance measured by three measures, namely Return on Assets (ROA), Return on Equity (ROE) and Price to Earnings ratio (PE). The results revealed that both ROE and ROA correlate with some of the disclosure variables. However, these variables differ from one sector to the other. Very few variables correlate with the PE ratio. The result confirms results achieved by previous studies conducted on the local and international level.
\end{abstract}

Keywords: corporate governance, financial disclosure, transparency, performance measurement, Saudi Arabia

\section{Introduction}

The Saudi Arabian Capital Market Authority (Board of Capital Market Authority, 2006) has issued Corporate Governance Regulations in 2006, which affected the information included on the annual reports of listed corporations. Such regulation resulted in increasing the content and amount of information provided by companies. Owners' capital structure and information related to the board of directors are presented in more details in the annual report. Companies also increased the level of details regarding financial and operational information.

The standard-setting role of the Capital Market authority was essentially exercised through the issuance of listing, ongoing disclosure, maintenance and de-listing requirements. On the enforcement side, stock exchanges have shared their regulatory function with capital market supervisory agencies. In addition to overseeing their own rules, the stock exchanges were assigned the role of monitoring compliance with the legislation and subsidiary securities regulation. They have contributed to the development of corporate governance recommendations and encouraged their application to listed companies (Christiansen \& Koldertsova, 2009).

Corporate Governance had been a hot issue during the last decade. Corporate governance refers to internal and external monitoring mechanisms that have an impact on the decision of managers in the context of separation of ownership and control. (Donker, Poff, \& Zahir, 2008) There are many studies in the field of Corporate Governance. Those studies aimed to find if there is a relationship between Corporate Governance and company performance. Some scholars (Mohd Hassan Che Haat, Rashidah Abdul Rahman, \& Mahenthiran, 2008), examined the effects of internal governance mechanisms, financing factors/ownership structure and audit quality on disclosure, timeliness and company performance. The study strongly suggested that corporate governance matters for the performance of firms in the market, even though the internal governance mechanisms do not have a strong influence on company performance. However, regressing the corporate governance variables against the level of disclosure and timeliness of reporting indicates that it does not influence them. The findings from this study show that there is no relationship between the level of disclosure and market performance. This study 
reveals that the framework of governance that is adopted by the regulatory bodies could be built in a way that does not fulfill its purposes. On the other hand, there are other scholars (Larcker, Richardson, \& Tuna, 2007), who found out that the relationship between typical measures of corporate governance and various accounting and economic outcomes has not produced a consistent set of results. Their research suggests that there are 14 dimensions to corporate governance and found that they have mixed associations with abnormal accruals, little relation to accounting restatements, but some ability to explain future operating performance and future excess stock returns. Most of the studies concentrate on companies operating in developed countries. There are very few research that studied the effect of Corporate Governance on a company's performance in developing countries. On the other hand, some studies lead to conflicting results.

This research aims to find the relationship of corporate governance regulations imposed by the Saudi Capital Market Authority - which implies disclosing particular information on the annual reports - and companies' performance in Saudi Arabia. A study (S\&P/hawkamah ESG pan Arab index methodology, 2013) classified Corporate Governance information into four main categories, each of which is composed of different variables. The four categories are; Ownership structure and shareholders' rights; board of directors' information; financial information; operational information. This research will be following such classification.

\section{Literature Review}

Reviewing the literature revealed that there are several studies that had discussed the relationship between disclosing information - as per corporate governance regulations - and company performance for each of those categories as follows:

\subsection{Ownership Structure and Shareholders' Rights}

The connection between ownership structure and performance has been the subject of a major and ongoing debate in the corporate finance literature. Studies revealed that ownership structure could differ from one country to the other. Indian companies, for example, maintain their shareholding pattern over time, unlike several other emerging markets (Kaur \& Gill, 2009). A study (Xiaonian Xu, 1999) found that the mix and concentration of share ownership did indeed significantly affect a company's performance. Another paper (Gropp \& Köhler, 2010) showed that banks working in countries with better shareholder rights and controlling shareholder recorded larger losses during the crisis than banks operating in countries with poor shareholder rights and without a controlling shareholder.

\subsection{Financial Information Disclosures}

A study (Abed, Al-Okdeh, \& Nimer, 2011) concluded that disclosing information related to forecasts is negatively and significantly related to performance when applied to Jordanian companies. Another study (Foerster \& Huen, 2004) found positive and significant relation between stock performance and the corporate governance score index for Canadian companies. Another research (Adiloglu \& Vuran, 2012) studied the relationship between the financial ratios and transparency levels of financial disclosures within the scope of corporate governance. The results reveal that transparency level has statistical differences among the group means of return on assets, total debt/ total assets, long-term debt/ total assets and corporate governance index variables. Another study (Nuryaman, 2012) pointed out that the practice of corporate governance has a positive effect on company's operational performance represented in the current ratio, return on assets and return on equity.

\subsection{Operational Information Disclosures}

Several studies covered the effect of operational information disclosure on company performance. A study (Brown \& Caylor, 2009) found that six corporate governance provisions were significantly and positively linked to return on assets, return on equity, or both. The research results revealed that the governance provisions recently mandated by the U.S. stock exchanges are less closely linked to firm operating performance than are those not so mandated. Another research (Aluchna, 2009) tried to measure the effect of corporate governance on company performance in Poland. The results do not confirm the assumption that higher ROI for companies that are complying with corporate governance best practice. These findings may be explained by the early stages of capital market development, weak institutional system and relative underdevelopment of the corporate governance system. The study concludes finally that the results may discourage companies for making further corporate governance progress or even for adopting the more fundamental rules of best practice. Thus, the compliance with corporate governance rules may be seen just a cost and formal requirement with no benefits for companies and investors. Another paper (Fong \& Shek, 2009) concluded that only two financial ratios (Operating Profit Margin and Net Profit Margin) that showed a positive relationship with Corporate Governance 
disclosure of Hong-Kong based family controlled property development companies. Other financial performance measuring ratios did not show such relationship. Al-Hussain (Al-Hussain \& Johnson, 2009) had the same results on Banks in Saudi Arabia. They found that there is a strong relationship between the efficiency of corporate governance structure and banks' performance measured by return on assets.

\subsection{Board of Directors Related Information}

Several studies covered the effect of disclosing information related to board of directors on company performance. A study (Bhagat Sanjai \& Bolton, September 2006) found that stock ownership of board members is significantly positively correlated with better contemporaneous and subsequent operating performance. Another research (Hua, 2003) found that the excess compensation in board and ownership structure has a negative association with firms' operating performance measured by return on assets.

It is clear from the literature review that there is no clear evidence for the impact of disclosure as per corporate governance regulations on company performance. Such ambiguity adds value to this paper as it sheds some light on such relationship in the Saudi Arabian context.

\section{Data Collection}

\subsection{Selecting the Variables of Disclosure as per Corporate Governance}

Following the classification of corporate governance into four main categories with their associated variables, the researcher reviewed their presence in the Saudi Arabian listed companies' annual reports. Each category contains a group of independent variables. Accordingly, the measures of disclosures are represented by 18 independent variables divided into the four categories as follows:

Disclosure of capital structure: Represented by four variables as follows:

- $\quad \mathrm{X} 1 \_1 \quad$ Number of shares.

- $\quad$ X1_2 Capital structure (Percent of equity to debt).

- $\quad$ X1_3 Percent of management ownership.

- X1_4 Institutional ownership.

Disclosure of Board of director's information: Represented by five variables as follows:

- $\quad$ X2_1 Number of meetings per year.

- $\quad$ X2_2 Number of members of Board of directors.

- $\quad \mathrm{X} 2 \_3$ Percent of attendance at meetings.

- $\quad$ X2_4 Number of independent board members.

- X2_5 Board members' compensation.

Disclosure of Financial information: Represented by four variables as follows:

- $\quad$ X3_1 Basic prediction of future revenues.

- $\quad$ X3_2 An analysis of the company's activities.

- $\quad$ X3_3 Revenue break-down.

- X3_4 Cost structure.

Disclosure of Operational information: Represented by five variables as follows:

- $\quad$ X4_1 Management discussion of the company's strategy.

- $\quad$ X4_2 Future investment plans.

- $\quad$ X4_3 Trends in the company's field of business.

- X4_4 Company's market share.

- X4_5 Participation in Social responsibility.

The dependent variables are represented as follows:

- Y1 Price to Earnings Ratio (PE).

- Y2 Return on Equity (ROE).

- Y3 Return on Assets (ROA). 


\subsection{Selecting the Performance Measures}

Based on the literature review, it is clear that most of the scholars agreed that performance measurement is represented by two financial indicators namely, return on assets and returns on Equity. In this research, the Price to Earnings ratio is added as the market performance measure.

\section{Sample Selection and Developing the Research Hypotheses}

\subsection{Sample Selection}

This research tests a group of hypotheses to formulate the relationship between companies' performance and corporate governance variables in three different sectors. The Banking sector; The Cement sector; and the Multi-Investment sector. The Banking sector is selected as it is strictly monitored by the Saudi Arabian Monetary Agency (SAMA - which is taking the role of the Central Bank in Saudi Arabia); so it is expected that it would be the sector that is applying the highest level of disclosures required by the Corporate Governance regulation. The multi-Investment sector works in various industries and hence the performance of its companies is not so directly affected by the market as those industry specific sectors. The Cement sector is selected as an industry specific sector that is the least sector affected by the economic environment during the period of study in Saudi Arabia as there is always an enormous demand for their products, and accordingly there are minimum market fluctuations. Company performance is determined by three performance indicators forming the dependent variables represented in return on assets (to show the efficiency of using the assets) "Y1," return on equity "Y2" (to show the profitability to shareholders) and Price to earnings ratio "Y3" (to show the response of the stock market).

The following figure summarizes the theoretical framework of this research where the relationship between each of those variables is tested for each of the three sectors, and then, the results are going to be compared to see if there are any discrepancies between sectors.

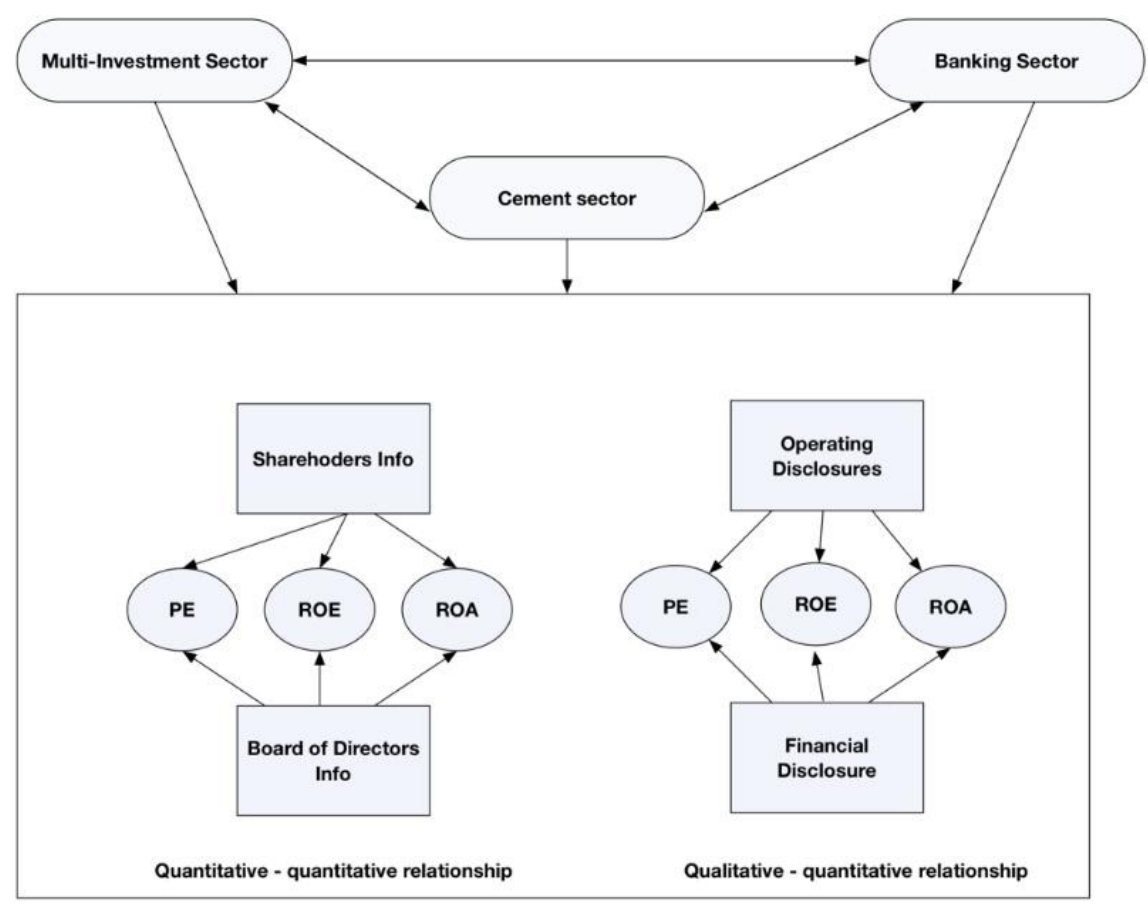

Figure 1. The research theoretical framework

\subsection{Developing the Research Hypotheses}

Based on the above theoretical framework, the research hypotheses are developed as follows:

H1: The relationship between the PE ratio and the Board of directors' disclosed information differs significantly among the different sectors.

H2: The relationship between the PE ratio and the disclosure of capital structure information differs significantly 
among the different sectors.

H3: The effect of the disclosure of financial information on PE ratio differs significantly among the different sectors.

H4: The effect of the disclosure of operational information on PE ratio differs significantly among the different sectors.

H5: The relationship between the ROE ratio and the Board of directors' disclosed information differ significantly among the different sectors.

H6: The relationship between the ROE ratio and the disclosure of capital structure information differs significantly among the different sectors.

H7: The effect of the disclosure of financial information on ROE ratio differs significantly among the different sectors.

H8: The effect of the disclosure of operational information on ROE ratio differs significantly among the different sectors.

H9: The relationship between the ROA ratio and the Board of directors' disclosed information differs significantly among the different sectors.

H10: The relationship between the ROA ratio and the disclosure of capital structure information differs significantly among the different sectors.

H11: The effect of the disclosure of financial information on ROA ratio differs significantly among the different sectors.

H12: The effect of the disclosure of operational information on ROA ratio differs significantly among the different sectors.

\section{Research Methodology}

Cross-sectional data (of 3 sectors) over a time series of ( 3 years) are compared together for the three chosen sectors by using panel data. The sample primarily included all companies in each of the three sector. Then, newly established companies that didn't have enough financial data to cover the series of years considered in this study are excluded (Note 1). The financial statements together with Board's reports for each company for each year are downloaded from the official site of the Saudi Stock market (www.tadawul.com). The data representing the respective variables are extracted from such reports into the statistical package SPSS where the statistical analysis is performed and hypotheses are tested.

\subsection{Statistical Analysis}

A descriptive analysis of the different variables (dependent/independent) is performed to plot whether there are any significant differences between those variables across the different sectors.

\subsubsection{Dependent Variables}

The following tables (table $1 \& 2$ ) show the descriptive statistics for the dependent variables.

Table 1. Descriptive statistics for the three sectors

\begin{tabular}{llccccc}
\hline sector & & $\mathrm{N}$ & Minimum & Maximum & Mean & Std. Deviation \\
\hline Banks & Y1 - PE & 33 & .00 & 1000.00 & 59.43 & 175.04 \\
& Y2 - ROE & 33 & -8.27 & 23.55 & 10.68 & 7.47 \\
& Y3 - ROA & 33 & -1.43 & 3.96 & 1.60 & 1.14 \\
\multirow{3}{*}{ Cement } & Y1 - PE & 27 & .00 & 107.48 & 15.46 & 18.95 \\
& Y2 - ROE & 27 & -3.28 & 33.83 & 17.12 & 9.68 \\
& Y3 - ROA & 27 & -2.82 & 29.94 & 14.02 & 8.71 \\
\multirow{3}{*}{ Multi Investment } & Y1 - PE & 21 & .00 & 1000.00 & 161.10 & 274.08 \\
& Y2 - ROE & 21 & -6.82 & 9.66 & 1.42 & 3.27 \\
& Y3 - ROA & 21 & -5.49 & 7.45 & 1.08 & 2.63 \\
\hline
\end{tabular}


Table 2. Dependent variables variance analysis based on each sector ANOVA

\begin{tabular}{llccccc}
\hline & & Sum of Squares & df & Mean Square & F & Sig. \\
\hline Y1 - PE & Between Groups & 258184 & 2 & 129092 & 4.040 & .021 \\
& Within Groups & 2492184 & 78 & 31951 & & \\
Y2- ROE & Total & 2750369 & 80 & & & .000 \\
& Between Groups & 2914 & 2 & 1457 & 25.618 & \\
& Within Groups & 4436 & 78 & 57 & & .000 \\
Y3 - ROA & Total & 7350 & 80 & & & \\
& Between Groups & 2871 & 2 & 1435 & & \\
\end{tabular}

Table 1 and 2 concludes that there are significant differences between the means of each of the dependent variables across sectors. Such a result is expected due to the different nature of each sector.

\subsubsection{Independent Variables}

Ownership structure and shareholders' rights: The following two tables (table $3 \& 4$ ) show the descriptive statistics on the four variables comprising such a category.

Table 3. Descriptive statistics for ownership structure and shareholders' right variables

\begin{tabular}{|c|c|c|c|c|c|c|}
\hline sector & & $\mathrm{N}$ & Minimum & Maximum & Mean & Std. Deviation \\
\hline \multirow[t]{4}{*}{ Banking } & X1_1 & 33 & 450000 & 1500000000 & 455565909 & 474211224 \\
\hline & $\mathrm{X} 1 \_2$ & 33 & 10 & 90 & 18 & 15 \\
\hline & X1_3 & 33 & 0 & 33 & 8 & 9 \\
\hline & $X 1 \_4$ & 33 & 0 & 66 & 20 & 22 \\
\hline \multirow[t]{4}{*}{ Cement } & $\mathrm{X} 1 \_1$ & 27 & 8000000 & 153000000 & 84966667 & 46509875 \\
\hline & $\mathrm{X} 1 \_2$ & 27 & 59 & 92 & 79 & 11 \\
\hline & $\mathrm{X} 1 \_3$ & 27 & 0 & 62 & 21 & 21 \\
\hline & X1_4 & 27 & 0 & 13 & 3 & 5 \\
\hline \multirow{4}{*}{$\begin{array}{l}\text { Multi- } \\
\text { Investment }\end{array}$} & $\mathrm{X} 1 \_1$ & 21 & 15000000 & 126388889 & 54226984 & 36125678 \\
\hline & $\mathrm{X} 1 \_2$ & 21 & 42 & 100 & 78 & 20 \\
\hline & $\mathrm{X} 1 \_3$ & 21 & 0 & 22 & 5 & 6 \\
\hline & X1_4 & 21 & 0 & 0 & 0 & 0 \\
\hline
\end{tabular}

Table 4. Variance analysis (ANOVA) for ownership structure and shareholders' rights variables according to the sector

\begin{tabular}{llccccc}
\hline & & Sum of Squares & df & Mean Square & F & Sig. \\
\hline X1_1 & Between Groups & $2.895 \mathrm{E} 18$ & 2 & $1.448 \mathrm{E} 18$ & 15.515 & .000 \\
& Within Groups & $7.278 \mathrm{E} 18$ & 78 & $9.331 \mathrm{E} 16$ & & \\
& Total & $1.017 \mathrm{E} 19$ & 80 & & & \\
X1_2 & Between Groups & 72561.033 & 2 & 36280.517 & 151.748 & .000 \\
& Within Groups & 18648.607 & 78 & 239.085 & & \\
& Total & 91209.640 & 80 & & & \\
\hline
\end{tabular}




\begin{tabular}{|c|c|c|c|c|c|c|}
\hline \multirow[t]{3}{*}{ X1_3 } & Between Groups & 3691.636 & 2 & 1845.818 & 9.882 & .000 \\
\hline & Within Groups & 14568.755 & 78 & 186.779 & & \\
\hline & Total & 18260.391 & 80 & & & \\
\hline \multirow[t]{3}{*}{ X1_4 } & Between Groups & 6775.365 & 2 & 3387.683 & 15.711 & .000 \\
\hline & Within Groups & 16818.976 & 78 & 215.628 & & \\
\hline & Total & 23594.341 & 80 & & & \\
\hline
\end{tabular}

It could be concluded that there is a significant difference between each of the independent variables across sectors as follows:

- The number of shares is significantly different due to the different capital requirements for the companies working in each of the sectors, considering the fact that all shares in Saudi Arabia are having the same par value of $10 \mathrm{SR}$.

- The capital structure is significantly different; however, it is close between the Cement sector and the multi-investment, while it is different in the banking sector, and such results are logical due to the different nature of such sector.

- The proportion of management shareholding is significantly different among sectors. Such results could appear to be illogical. However, in Saudi Arabia, it is different, as there are a couple of banks owned by families who are participating in management.

- Proportion of institutional shareholding is significantly different among sectors too. Where the Cement and the banking sector showed participation of institutional shareholding, while the multi-investment showed no institutional shareholding.

Board and Management Information: Descriptive statistics for the five indicators comprising such variables is shown in (Table $5 \& 6$ ) as follows:

Table 5. Descriptive statistics for board and management information variables

\begin{tabular}{llccccc}
\hline sector & & N & Minimum & Maximum & Mean & Std. Deviation \\
\hline Banking & X2_1 & 28 & 4 & 8 & 5 & 1 \\
& X2_2 & 33 & 6 & 11 & 10 & 1 \\
& X2_3 & 28 & 72 & 100 & 89 & 6 \\
Cement & X2_4 & 32 & 25 & 100 & 65 & 23 \\
& X2_5 & 31 & 1380 & 27892 & 6990 & 7439 \\
& X2_1 & 26 & 4 & 9 & 5 & 1 \\
& X2_2 & 26 & 7 & 11 & 9 & 2 \\
X2_3 & 26 & 67 & 100 & 87 & 9 \\
X2_4 & 25 & 25 & 100 & 65 & 23 \\
X2_5 & 26 & 1581 & 6278 & 3054 & 1373
\end{tabular}


Table 6. Variance analysis (ANOVA) for board \& management information variables according to sector

\begin{tabular}{|c|c|c|c|c|c|c|}
\hline & & Sum of Squares & $\mathrm{df}$ & Mean Square & $\mathrm{F}$ & Sig. \\
\hline \multirow[t]{3}{*}{ X2_1 } & Between Groups & .126 & 2 & .063 & .025 & .976 \\
\hline & Within Groups & 183.420 & 72 & 2.548 & & \\
\hline & Total & 183.547 & 74 & & & \\
\hline \multirow[t]{3}{*}{$\mathrm{X} 2 \_2$} & Between Groups & 62.670 & 2 & 31.335 & 18.166 & .000 \\
\hline & Within Groups & 132.818 & 77 & 1.725 & & \\
\hline & Total & 195.487 & 79 & & & \\
\hline \multirow[t]{3}{*}{$\mathrm{X} 2 \_3$} & Between Groups & 353.726 & 2 & 176.863 & 2.429 & .095 \\
\hline & Within Groups & 5243.104 & 72 & 72.821 & & \\
\hline & Total & 5596.830 & 74 & & & \\
\hline \multirow[t]{3}{*}{ X2_4 } & Between Groups & 1566.730 & 2 & 783.365 & 1.568 & .216 \\
\hline & Within Groups & 35476.224 & 71 & 499.665 & & \\
\hline & Total & 37042.955 & 73 & & & \\
\hline \multirow[t]{3}{*}{$\mathrm{X} 2 \_5$} & Between Groups & 3.7838 & 2 & 1.8928 & 7.517 & .001 \\
\hline & Within Groups & 1.8129 & 72 & 2.5167 & & \\
\hline & Total & 2.1909 & 74 & & & \\
\hline
\end{tabular}

The above tables conclude that there is no significant difference between the number of meetings, percent of attended meetings by members and the number of independent board members across sectors. However, there is a significant difference between the number of board of directors' members and the executive board compensation across sectors. It could be rational that the executive board compensation is significantly higher in banks as their operations and investments are higher than the other two sectors.

\section{Disclosure of financial information:}

Due to the qualitative nature of the data, the descriptive statistics used cross tabulation, where all the indicators are descriptive value, taking the value of either " 1 " if present or " 0 " if absent. Chi-Square has been used to test whether there is a significant difference across sectors.

Table 7. Cross tabulation frequency tables for the financial disclosure variables according to sector

\begin{tabular}{|c|c|c|c|c|c|c|c|c|c|}
\hline \multirow{2}{*}{$\begin{array}{l}\text { sector } \\
\text { Variables }\end{array}$} & & \multicolumn{2}{|c|}{ Banking } & \multicolumn{2}{|c|}{ Cement } & \multicolumn{2}{|c|}{ Multi-Investment } & \multicolumn{2}{|c|}{ Total } \\
\hline & & No. & $\%$ & No. & $\%$ & No. & $\%$ & No. & $\%$ \\
\hline \multirow[t]{2}{*}{ X3_1 } & 0 & 8 & $24.2 \%$ & 7 & $25.9 \%$ & 0 & $.0 \%$ & 15 & $18.5 \%$ \\
\hline & 1 & 25 & $75.8 \%$ & 20 & $74.1 \%$ & 21 & $100.0 \%$ & 66 & $81.5 \%$ \\
\hline Total & & 33 & $100.0 \%$ & 27 & $100.0 \%$ & 21 & $100.0 \%$ & 81 & $100.0 \%$ \\
\hline \multirow[t]{2}{*}{$\mathrm{X} 3 \_2$} & 0 & 10 & $30.3 \%$ & 9 & $33.3 \%$ & 6 & $28.6 \%$ & 25 & $30.9 \%$ \\
\hline & 1 & 23 & $69.7 \%$ & 18 & $66.7 \%$ & 15 & $71.4 \%$ & 56 & $69.1 \%$ \\
\hline Total & & 33 & $100.0 \%$ & 27 & $100.0 \%$ & 21 & $100.0 \%$ & 81 & $100.0 \%$ \\
\hline \multirow[t]{2}{*}{$\mathrm{X} 3 \_3$} & 0 & 1 & $3.0 \%$ & 9 & $33.3 \%$ & 6 & $28.6 \%$ & 16 & $19.8 \%$ \\
\hline & 1 & 32 & $97.0 \%$ & 18 & $66.7 \%$ & 15 & $71.4 \%$ & 65 & $80.2 \%$ \\
\hline Total & & 33 & $100.0 \%$ & 27 & $100.0 \%$ & 21 & $100.0 \%$ & 81 & $100.0 \%$ \\
\hline \multirow[t]{2}{*}{ X3_4 } & 0 & 16 & $48.5 \%$ & 27 & $100.0 \%$ & 18 & $85.7 \%$ & 61 & $75.3 \%$ \\
\hline & 1 & 17 & $51.5 \%$ & 0 & $.0 \%$ & 3 & $14.3 \%$ & 20 & $24.7 \%$ \\
\hline Total & & 33 & $100.0 \%$ & 27 & $100.0 \%$ & 21 & $100.0 \%$ & 81 & $100.0 \%$ \\
\hline
\end{tabular}


Table 8. Chi-square test for the financial disclosure variables according to sector

\begin{tabular}{lccc}
\hline Variable & Chi Square & df & Sig. \\
\hline X3_1 & 6.471 & 2 & 0.039 \\
X3_2 & 0.134 & 2 & 0.935 \\
X3_3 & 9.994 & 2 & 0.007 \\
X3_4 & 22.845 & 2 & 0.000 \\
\hline
\end{tabular}

Based on the results provided in tables $7 \& 8$, the following could be concluded regarding each of the independent variables:

- There is a significant difference across sectors in basic earnings forecast. It is clear that the multi-investment companies are disclosing such forecasts while banks and Cement companies are disclosing significantly less information.

- There is no significant difference across sectors regarding segment analysis where results are broken down to the business line level. The percentage of such disclosure among companies in different sectors is close, where the highest level of disclosure is among the multi-investment, banking and Cement sectors respectively.

- Revenue structure disclosure is significantly different across sectors. The percent is higher in banks, then multi-investment and the least percent is in the Cement sector.

- Analysis of the cost structure is significantly different across sectors. However, for all sectors the percent has been very small. The Cement sector does not show any disclosure regarding this variable.

Based on the above analysis, it is clear that the Cement sector does not disclose financial information as the other two sectors.

Operational Disclosure: Cross tabulation is used due to the qualitative nature of the data where all the variables are descriptive.

Table 9. Cross tabulation frequency tables for the operational disclosure variables according to sectors

\begin{tabular}{|c|c|c|c|c|c|c|c|c|c|}
\hline \multirow[b]{3}{*}{ Variables } & & \multicolumn{6}{|c|}{ sectors } & \multirow{2}{*}{\multicolumn{2}{|c|}{ Total }} \\
\hline & & \multicolumn{2}{|c|}{ Banking } & \multicolumn{2}{|c|}{ Cement } & \multicolumn{2}{|c|}{ Multi-Investment } & & \\
\hline & & Number & $\%$ & Number & $\%$ & Number & $\%$ & Number & $\%$ \\
\hline \multirow[t]{2}{*}{ X4_1 } & 0 & 3 & $9.1 \%$ & 7 & $25.9 \%$ & 1 & $4.8 \%$ & 11 & $13.6 \%$ \\
\hline & 1 & 30 & $90.9 \%$ & 20 & $74.1 \%$ & 20 & $95.2 \%$ & 70 & $86.4 \%$ \\
\hline Total & & 33 & $100.0 \%$ & 27 & $100.0 \%$ & 21 & $100.0 \%$ & 81 & $100.0 \%$ \\
\hline \multirow[t]{2}{*}{$X 4 \_2$} & 0 & 6 & $18.2 \%$ & 9 & $33.3 \%$ & 4 & $19.0 \%$ & 19 & $23.5 \%$ \\
\hline & 1 & 27 & $81.8 \%$ & 18 & $66.7 \%$ & 17 & $81.0 \%$ & 62 & $76.5 \%$ \\
\hline Total & & 33 & $100.0 \%$ & 27 & $100.0 \%$ & 21 & $100.0 \%$ & 81 & $100.0 \%$ \\
\hline \multirow[t]{2}{*}{$\mathrm{X} 4 \_3$} & 0 & 16 & $48.5 \%$ & 15 & $55.6 \%$ & 13 & $61.9 \%$ & 44 & $54.3 \%$ \\
\hline & 1 & 17 & $51.5 \%$ & 12 & $44.4 \%$ & 8 & $38.1 \%$ & 37 & $45.7 \%$ \\
\hline Total & & 33 & $100.0 \%$ & 27 & $100.0 \%$ & 21 & $100.0 \%$ & 81 & $100.0 \%$ \\
\hline \multirow[t]{2}{*}{ X4_4 } & 0 & 24 & $72.7 \%$ & 15 & $55.6 \%$ & 18 & $85.7 \%$ & 57 & $70.4 \%$ \\
\hline & 1 & 9 & $27.3 \%$ & 12 & $44.4 \%$ & 3 & $14.3 \%$ & 24 & $29.6 \%$ \\
\hline Total & & 33 & $100.0 \%$ & 27 & $100.0 \%$ & 21 & $100.0 \%$ & 81 & $100.0 \%$ \\
\hline \multirow[t]{2}{*}{$X 4 \_5$} & 0 & 18 & $54.5 \%$ & 9 & $33.3 \%$ & 15 & $71.4 \%$ & 42 & $51.9 \%$ \\
\hline & 1 & 15 & $45.5 \%$ & 18 & $66.7 \%$ & 6 & $28.6 \%$ & 39 & $48.1 \%$ \\
\hline Total & & 33 & $100.0 \%$ & 27 & $100.0 \%$ & 21 & $100.0 \%$ & 81 & $100.0 \%$ \\
\hline
\end{tabular}


Table 10. Chi-square test operational disclosure variables according to sectors

\begin{tabular}{|c|c|c|c|}
\hline Variable & Chi Square & $\mathrm{df}$ & Sig. \\
\hline X4_1 & 5.465 & 2 & 0.065 \\
\hline$X 4 \_2$ & 2.206 & 2 & 0.332 \\
\hline $\mathrm{X} 4 \_3$ & 0.956 & 2 & 0.620 \\
\hline X4_4 & 5.301 & 2 & 0.071 \\
\hline X4_5 & 7.028 & 2 & 0.030 \\
\hline
\end{tabular}

Based on tables ( $9 \& 10)$, it could be concluded that there are no significant differences between the operational variables in between the sectors except for the participation for the social responsibility where it showed that there is a significant difference across the different sectors.

\section{Testing the Research Hypotheses}

The twelve hypotheses of this research are tested as follows:

6.1 Testing H1: The Relationship between the PE Ratio and the Board of Directors' Disclosed Information Differs Significantly among the Different Sectors

Pearson correlation coefficient is used to test the relationship between Y1 (PE ratio) and the disclosure of board of directors' information represented in the variables (X2_1, X2_2, X2_3, X2_4, X2_5) for each sector.

Table 11. Correlation coefficient between PE ratio and board of directors' disclosed information for each sector

\begin{tabular}{|c|c|c|c|c|c|c|c|}
\hline sector & & & $\mathrm{X} 2 \_1$ & $\mathrm{X} 2 \_2$ & $\mathrm{X} 2 \_3$ & $\mathrm{X} 2 \_4$ & $\mathrm{X} 2 \_5$ \\
\hline \multirow[t]{3}{*}{ Banking } & PE ratio & Pearson Correlation & .033 & -.196 & -.178 & .025 & -.004 \\
\hline & & Sig. (2-tailed) & .869 & .274 & .365 & .890 & .984 \\
\hline & & $\mathrm{N}$ & 28 & 33 & 28 & 32 & 31 \\
\hline \multirow[t]{3}{*}{ Cement } & PE ratio & Pearson Correlation & -.170 & -.353 & -.057 & .263 & $.483^{*}$ \\
\hline & & Sig. (2-tailed) & .405 & .077 & .782 & .205 & .012 \\
\hline & & $\mathrm{N}$ & 26 & 26 & 26 & 25 & 26 \\
\hline \multirow[t]{3}{*}{ Multi-Investment } & PE ratio & Pearson Correlation & .078 & -.298 & .146 & -.020 & -.018 \\
\hline & & Sig. (2-tailed) & .736 & .190 & .528 & .939 & .945 \\
\hline & & $\mathrm{N}$ & 21 & 21 & 21 & 17 & 18 \\
\hline
\end{tabular}

* Correlation is significant at the 0.05 level (2-tailed).

Based on the information provided in table 11, it could be concluded that there is no relationship between the PE ratio and the disclosure of information related to the board of directors. Hence, $\mathrm{H} 1$ is rejected.

6.2 Testing H2: The Relationship between the PE Ratio and the Disclosure of Capital Structure Information Differs Significantly among the Different Sectors

Pearson correlation coefficient is used to test the relationship between Y1 (PE ratio) and disclosure of capital structure information represented in the variables $\left(X 1 \_1, X 1 \_2, X 1 \_3, X 1 \_4\right)$ for each sector. 
Table 12. Correlation coefficient between PE ratio and capital structure for each sector

\begin{tabular}{|c|c|c|c|c|c|c|}
\hline sector & & & $\mathrm{X} 1 \_1$ & $\mathrm{X} 1 \_2$ & $\mathrm{X} 1 \_3$ & $X 1 \_4$ \\
\hline \multirow[t]{3}{*}{ Banking } & PE ratio & Pearson Correlation & .319 & $.471 * *$ & -.078 & .106 \\
\hline & & Sig. (2-tailed) & .070 & .006 & .666 & .556 \\
\hline & & $\mathrm{N}$ & 33 & 33 & 33 & 33 \\
\hline \multirow[t]{3}{*}{ Cement } & PE ratio & Pearson Correlation & .164 & -.091 & -.117 & -.063 \\
\hline & & Sig. (2-tailed) & .415 & .652 & .562 & .754 \\
\hline & & $\mathrm{N}$ & 27 & 27 & 27 & 27 \\
\hline \multirow[t]{3}{*}{ Multi-Investment } & PE ratio & Pearson Correlation & .004 & -.286 & -.136 &. $\mathrm{a}$ \\
\hline & & Sig. (2-tailed) & .988 & .208 & .558 & . \\
\hline & & $\mathrm{N}$ & 21 & 21 & 21 & 21 \\
\hline
\end{tabular}

** Correlation is significant at the 0.01 level (2-tailed).

a. Cannot be computed because at least one of the variables is constant.

Based on the information presented in table 12 the following could be concluded. There is a significant positive relationship between disclosing information of a bank's capital structure and its PE ratio.

- There are no other significant relationships between any of the other variables for the different sectors.

- Multi-investment companies do not have any institutional investors, and hence, the correlation coefficient in their case could not be computed for such a variable. Based on the above results $\mathrm{H} 2$ is rejected.

6.3 Testing H3: The Effect of the Disclosure of Financial Information on PE Ratio Differs Significantly among the Different Sectors

The relationship between Y1 (PE ratio) and the financial disclosures variables (X3_1, X3_2, X3_3, X3_4) for each sector is investigated to test this hypothesis. As the financial disclosures variable took the binary form where " 1 " (present) and " 0 " (absent), hence, the two independent samples T-Test has been used to study such relationship.

Table 13. T-test to plot the relationship between PE ratio and financial variables

\begin{tabular}{lllllll}
\hline sector & Variable Values & No. of values & Mean & St. Dev. & T-Test & Sig. \\
\hline X3_1 & & & & & & \\
Banking & 0 & 8 & 14.06 & 4.11 & -0.838 & 0.408 \\
& 1 & 25 & 73.95 & 199.96 & & \\
Cement & 0 & 7 & 11.39 & 5.17 & -0.654 & 0.519 \\
& 1 & 20 & 16.89 & 21.79 & & - \\
Multi-Investment & 0 & 0 & - & - & - & \\
& 1 & 21 & 161.10 & 274.08 & & \\
X3_2 & & & & & \\
Banking & 0 & 10 & 14.50 & 3.87 & -0.972 & \\
& 1 & 23 & 78.79 & 207.95 & & \\
Cement & 0 & 9 & 23.44 & 32.09 & -1.592 & 0.124 \\
& 1 & 18 & 11.47 & 3.74 & & \\
Multi-Investment & 0 & 6 & 104.86 & 83.23 & -0.585 & 0.566 \\
& 1 & 15 & 183.60 & 320.84 & & \\
\hline
\end{tabular}




\begin{tabular}{|c|c|c|c|c|c|c|}
\hline \multicolumn{7}{|l|}{$X 3 \_3$} \\
\hline \multirow[t]{2}{*}{ Banking } & 0 & 1 & 15.79 & - & -0.294 & 0.805 \\
\hline & 1 & 32 & 60.80 & 177.69 & & \\
\hline \multirow[t]{2}{*}{ Cement } & 0 & 9 & 23.44 & 32.09 & 1.592 & 0.124 \\
\hline & 1 & 18 & 11.47 & 3.74 & & \\
\hline \multirow[t]{2}{*}{ Multi-Investment } & 0 & 6 & 104.86 & 83.23 & -0.585 & 0.566 \\
\hline & 1 & 15 & 183.60 & 320.84 & & \\
\hline \multicolumn{7}{|l|}{$X 3 \_4$} \\
\hline \multirow[t]{2}{*}{ Banking } & 0 & 16 & 19.68 & 25.89 & -1.279 & 0.211 \\
\hline & 1 & 17 & 96.85 & 239.97 & & \\
\hline \multirow[t]{2}{*}{ Cement } & 0 & 27 & 15.48 & 18.95 & - & - \\
\hline & 1 & 0 & - & - & & \\
\hline \multirow[t]{2}{*}{ Multi-Investment } & 0 & 18 & 184.37 & 290.45 & 0.951 & 0.354 \\
\hline & 1 & 3 & 21.46 & 2.27 & & \\
\hline
\end{tabular}

This table shows that there are no significant differences for all variables in all sectors.

Based on the information presented in table 13, it is clear that there is no significant difference between the means of the dependent variables across the different sectors as $\mathrm{T}$ is insignificant. Hence, H3 is rejected.

6.4 Testing H4: The Effect of the Disclosure of Operational Information on PE Ratio Differs Significantly among the Different Sectors

The relationship between Y1 (PE ratio) and the disclosure of operational information variables (X4_1, X4_2, X4_3, X4_4, X4_5) for each sector is investigated. As the disclosure of operational information variables took the binary form where " 1 " (present) and " 0 " (absent), hence, the Two independent samples T-Test is used to study such relationship.

Table 14. T-test to plot the relationship between PE ratio and operational variables

\begin{tabular}{|c|c|c|c|c|c|c|}
\hline sector & Variable Values & No. of values & Mean & St. Dev. & T-Test & Sig. \\
\hline \multicolumn{7}{|l|}{$X 4 \_1$} \\
\hline \multirow[t]{2}{*}{ Banking } & 0 & 3 & 17.05 & 5.42 & -0.474 & 0.667 \\
\hline & 1 & 30 & 63.67 & 183.21 & & \\
\hline \multirow[t]{2}{*}{ Cement } & 0 & 7 & 11.75 & 5.23 & -0.595 & 0.557 \\
\hline & 1 & 20 & 16.76 & 21.81 & & \\
\hline \multirow[t]{2}{*}{ Multi-Investment } & 0 & 1 & 0 & - & -0.592 & 0.561 \\
\hline & 1 & 20 & 169.16 & 278.63 & & \\
\hline \multicolumn{7}{|l|}{$X 4 \_2$} \\
\hline \multirow[t]{2}{*}{ Banking } & 0 & 6 & 22.12 & 21.71 & -0.571 & 0.572 \\
\hline & 1 & 27 & 67.72 & 192.94 & & \\
\hline \multirow[t]{2}{*}{ Cement } & 0 & 9 & 11.72 & 4.52 & -0.719 & 0.479 \\
\hline & 1 & 18 & 17.33 & 22.99 & & \\
\hline \multirow[t]{2}{*}{ Multi-Investment } & 0 & 4 & 98.04 & 104.27 & -0.502 & 0.622 \\
\hline & 1 & 17 & 175.94 & 301.05 & & \\
\hline
\end{tabular}




\begin{tabular}{|c|c|c|c|c|c|c|}
\hline \multicolumn{7}{|l|}{$X 4 \_3$} \\
\hline \multirow[t]{2}{*}{ Banking } & 0 & 16 & 79.99 & 245.76 & 0.649 & 0.521 \\
\hline & 1 & 17 & 40.08 & 61.94 & & \\
\hline \multirow[t]{2}{*}{ Cement } & 0 & 15 & 18.98 & 24.92 & 1.083 & 0.289 \\
\hline & 1 & 12 & 11.06 & 4.48 & & \\
\hline \multirow[t]{2}{*}{ Multi-Investment } & 0 & 13 & 245.68 & 323.17 & 2.463 & 0.029 \\
\hline & 1 & 8 & 23.66 & 26.63 & & \\
\hline \multicolumn{7}{|l|}{$X 4 \_4$} \\
\hline \multirow[t]{2}{*}{ Banking } & 0 & 24 & 72.79 & 203.79 & 0.710 & 0.483 \\
\hline & 1 & 9 & 23.81 & 34.60 & & \\
\hline \multirow[t]{2}{*}{ Cement } & 0 & 15 & 18.98 & 24.92 & 1.083 & 0.289 \\
\hline & 1 & 12 & 11.06 & 4.48 & & \\
\hline \multirow[t]{2}{*}{ Multi-Investment } & 0 & 18 & 184.38 & 290.45 & 2.379 & 0.029 \\
\hline & 1 & 3 & 21.46 & 2.27 & & \\
\hline \multicolumn{7}{|l|}{$X 4 \_5$} \\
\hline \multirow[t]{2}{*}{ Banking } & 0 & 18 & 77.98 & 231.67 & 0.514 & 0.514 \\
\hline & 1 & 15 & 37.18 & 62.40 & & \\
\hline \multirow[t]{2}{*}{ Cement } & 0 & 9 & 11.49 & 4.57 & 0.452 & 0.452 \\
\hline & 1 & 18 & 17.45 & 22.95 & & \\
\hline \multirow[t]{2}{*}{ Multi-Investment } & 0 & 15 & 191.07 & 318.55 & 0.442 & 0.442 \\
\hline & 1 & 6 & 86.18 & 83.13 & & \\
\hline
\end{tabular}

Based on the information presented in table 14, it could be concluded that there is a significant effect of the concealed operational information on the PE ratio in the Multi-Investment sector related to industry trends, and information related to company's market share. Otherwise, there is no significant effect on PE ratios between the different sectors regarding the other variables. Hence, it does not differ significantly from the other sectors and therefore $\mathrm{H} 4$ is failed to reject.

6.5 Testing H5: The Relationship between the ROE Ratio and the Board of Director's Disclosed Information Differ Significantly among the Different Sectors

Pearson correlation coefficient is used to test the relationship between Y2 (Return on Equity) and the disclosure of board of director's information represented in the variables (X2_1, X2_2, X2_3, X2_4, X2_5) for each sector.

Table 15. Correlation coefficient between ROE ratio and board of directors' disclosed information for each sector

\begin{tabular}{|c|c|c|c|c|c|c|c|}
\hline sector & & & $\mathrm{X} 2 \_1$ & $\mathrm{X} 2 \_2$ & $\mathrm{X} 2 \_3$ & $\mathrm{X} 2 \_4$ & $\mathrm{X} 2 \_5$ \\
\hline \multirow[t]{3}{*}{ Banking } & ROE & Pearson Correlation & .203 & .084 & $.552 * *$ & $-.475 * *$ & -.250 \\
\hline & & Sig. (2-tailed) & .300 & .644 & .002 & .006 & .175 \\
\hline & & $\mathrm{N}$ & 28 & 33 & 28 & 32 & 31 \\
\hline \multirow[t]{3}{*}{ Cement } & ROE & Pearson Correlation & .271 & .207 & $.439^{*}$ & $-.230-$ & -.017 \\
\hline & & Sig. (2-tailed) & .181 & .311 & .025 & .268 & .932 \\
\hline & & $\mathrm{N}$ & 26 & 26 & 26 & 25 & 26 \\
\hline \multirow[t]{3}{*}{ Multi-Investment } & ROE & Pearson Correlation & -.233 & -.279 & -.089 & .183 & -.003 \\
\hline & & Sig. (2-tailed) & .309 & .221 & .702 & .483 & .989 \\
\hline & & $\mathrm{N}$ & 21 & 21 & 21 & 17 & 18 \\
\hline
\end{tabular}

**. Correlation is significant at the 0.01 level (2-tailed).

*. Correlation is significant at the 0.05 level (2-tailed). 
Based on the information presented in table 15, it is clear that there is a correlation between ROE and attendance of meeting in the banking and Cement sectors. However, there is a negative correlation between the number of independent board members and ROE in the banking sector. No correlation is between such variables and ROE in the Multi-Investment sector. Accordingly $\mathrm{H} 5$ is failed to reject.

6.6 Testing H6: The Relationship between the ROE Ratio and the Disclosure of Capital Structure Information Differs Significantly among the Different Sectors

Pearson correlation coefficient is used to test the relationship between Y2 (Return on Equity) and disclosure of capital structure information represented in the variables $\left(\mathrm{X} 1 \_1, \mathrm{X} 1 \_2, \mathrm{X} 1 \_3, \mathrm{X} 1 \_4\right)$ for each sector.

Table 16. Correlation coefficient between ROE ratio and the capital structure

\begin{tabular}{|c|c|c|c|c|c|c|}
\hline sector & & & $\mathrm{X} 1 \_1$ & $\mathrm{X} 1 \_2$ & $\mathrm{X} 1 \_3$ & $X 1 \_4$ \\
\hline \multirow[t]{3}{*}{ Banking } & \multirow[t]{3}{*}{ ROE } & Pearson Correlation & .037 & -.296 & .258 & -.063 \\
\hline & & Sig. (2-tailed) & .839 & .094 & .147 & .726 \\
\hline & & $\mathrm{N}$ & 33 & 33 & 33 & 33 \\
\hline \multirow[t]{3}{*}{ Cement } & \multirow[t]{3}{*}{ ROE } & Pearson Correlation & -.122 & $.464 *$ & $.635^{* *}$ & .053 \\
\hline & & Sig. (2-tailed) & .546 & .015 & .000 & .795 \\
\hline & & $\mathrm{N}$ & 27 & 27 & 27 & 27 \\
\hline \multirow[t]{3}{*}{ Multi-Investment } & \multirow[t]{3}{*}{ ROE } & Pearson Correlation & .392 & -.054 & .140 &. $\mathrm{a}$ \\
\hline & & Sig. (2-tailed) & .079 & .818 & .546 & . \\
\hline & & $\mathrm{N}$ & 21 & 21 & 21 & 21 \\
\hline
\end{tabular}

**. Correlation is significant at the 0.01 level (2-tailed).

a. Cannot be computed because at least one of the variables is constant.

Based on the information presented in table 16, it could be concluded that there is a significant positive correlation between disclosing information regarding the company's capital structure and ROE. Such results are logical. There is also a positive correlation between the percent of management shareholding and ROE. Those results are also logical due to the concern and involvement of the management in steering the company to success. However, it is of interest that this is not the case in the other two sectors. Also, there is no significant correlation between any of the variables and ROE for the banking and multi-investment sector. Accordingly H6 is failed to reject.

\subsection{Testing H7: The Effect of the Disclosure of Financial Information on ROE Ratio Differs Significantly among} the Different Sectors

The relationship between Y2 (Return on Equity) and the disclosure of financial information variables (X3_1, X3_2, X3_3, X3_4) for each sector is investigated. As the disclosure of financial information variables took the binary form where " 1 " (present) and "0" (absent), hence, the Two independent samples T-Test has been used to study such relationship.

Table 17. T-Test to plot the relationship between ROE ratio and financial variables

\begin{tabular}{|c|c|c|c|c|c|c|}
\hline sector & Variable Values & No. of values & Mean & St. Dev. & T-Test & Sig. \\
\hline \multicolumn{7}{|l|}{$X 3 \_1$} \\
\hline \multirow[t]{2}{*}{ Banking } & 0 & 8 & 13.33 & 6.06 & 1.160 & 0.255 \\
\hline & 1 & 25 & 8.83 & 7.78 & & \\
\hline \multirow[t]{2}{*}{ Cement } & 0 & 7 & 11.81 & 7.13 & \multirow[t]{2}{*}{-1.751} & \multirow{2}{*}{0.092} \\
\hline & 1 & 20 & 18.97 & 9.91 & & \\
\hline \multirow[t]{2}{*}{ Multi-Investment } & 0 & 0 & - & - & \multirow{2}{*}{-} & \multirow{2}{*}{ - } \\
\hline & 1 & 21 & 1.42 & 3.27 & & \\
\hline
\end{tabular}




\begin{tabular}{|c|c|c|c|c|c|c|}
\hline$X 3 \_2$ & & & & & & \\
\hline \multirow[t]{2}{*}{ Banking } & 0 & 10 & 15.14 & 6.58 & \multirow[t]{2}{*}{2.433} & \multirow{2}{*}{0.021} \\
\hline & 1 & 23 & 8.74 & 7.10 & & \\
\hline \multirow[t]{2}{*}{ Cement } & 0 & 9 & 9.99 & 7.25 & \multirow[t]{2}{*}{-3.126} & \multirow{2}{*}{0.004} \\
\hline & 1 & 18 & 20.68 & 8.85 & & \\
\hline \multirow[t]{2}{*}{ Multi-Investment } & 0 & 6 & 2.20 & 1.59 & \multirow{2}{*}{0.677} & \multirow{2}{*}{0.508} \\
\hline & 1 & 15 & 1.11 & 3.75 & & \\
\hline \multicolumn{7}{|l|}{$X 3 \_3$} \\
\hline \multirow[t]{2}{*}{ Banking } & 0 & 1 & 22.55 & - & \multirow{2}{*}{1.812} & \multirow{2}{*}{0.080} \\
\hline & 1 & 32 & 10.28 & 7.21 & & \\
\hline \multirow[t]{2}{*}{ Cement } & 0 & 9 & 9.99 & 7.25 & \multirow{2}{*}{$3.126-$} & \multirow{2}{*}{0.004} \\
\hline & 1 & 18 & 20.68 & 8.85 & & \\
\hline \multirow[t]{2}{*}{ Multi-Investment } & 0 & 6 & 2.20 & 1.59 & \multirow{2}{*}{0.677} & \multirow{2}{*}{0.506} \\
\hline & 1 & 15 & 1.11 & 3.75 & & \\
\hline \multicolumn{7}{|l|}{$X 3 \_4$} \\
\hline \multirow[t]{2}{*}{ Banking } & 0 & 16 & 14.53 & 6.38 & \multirow{2}{*}{2.284} & \multirow{2}{*}{0.003} \\
\hline & 1 & 17 & 7.05 & 6.68 & & \\
\hline \multirow[t]{2}{*}{ Cement } & 0 & 27 & 17.12 & 9.68 & \multirow{2}{*}{-} & \multirow{2}{*}{-} \\
\hline & 1 & 0 & - & - & & \\
\hline \multirow[t]{2}{*}{ Multi-Investment } & 0 & 18 & 1.03 & 3.38 & \multirow{2}{*}{$3.234-$} & \multirow{2}{*}{0.004} \\
\hline & 1 & 3 & 3.78 & 0.51 & & \\
\hline
\end{tabular}

Based on the results provided in table 17, it could be concluded that disclosing basic earnings forecast did not show any significant effect on ROE. However, there is a significant effect of concealing segment analysis on ROE in the banking sector Cement sector. Disclosing the analysis of the revenue structure significantly affects ROE in the Cement sector only. It could be concluded that disclosing the analysis of the cost structure affects ROE in both the Multi-Investment sector while concealing it affects ROE in the banking sector. Based on such significant effect of such variables on different sectors, it could be concluded that $\mathrm{H} 7$ is failed to reject.

6.8 Testing H8: The Effect of the Disclosure of Operational Information on ROE Ratio Differs Significantly among the Different Sectors

The relationship between Y2 (ROE) and the disclosure of operational information variables (X4_1, X4_2, X4_3, $\mathrm{X} 4 \_4, \mathrm{X} 4 \_5$ ) for each sector is studied. As the disclosure of operational variables took the binary form where "1" (present) and " 0 " (absent). Therefore, the two independent samples T-Test is used to study such relationship.

Table 18. T-test to plot the relationship between PE ratio and operational variables

\begin{tabular}{lllllll}
\hline sector & Variable Values & No. of values & Mean & St. Dev. & T-Test & Sig. \\
\hline X4_1 & & & & & & \\
Banking & 0 & 3 & 6.85 & 1.51 & $\mathbf{- 2 . 5 3 8}$ & $\mathbf{0 . 0 2 1}$ \\
& 1 & 30 & 11.06 & 7.73 & & 0.911 \\
Cement & 0 & 7 & 17.48 & 13.09 & 0.113 & 0.063 \\
& 1 & 20 & 16.99 & 8.61 & & -1.975 \\
\hline \multirow{2}{*}{ Multi-Investment } & 0 & 1 & -4.48 & - & & \\
& 1 & 20 & 1.71 & 3.06 & & \\
\hline
\end{tabular}




\begin{tabular}{|c|c|c|c|c|c|c|}
\hline$X 4 \_2$ & & & & & & \\
\hline \multirow[t]{2}{*}{ Banking } & 0 & 6 & 4.15 & 6.52 & \multirow[b]{2}{*}{-2.264} & \multirow[b]{2}{*}{0.015} \\
\hline & 1 & 27 & 12.13 & 6.96 & & \\
\hline \multirow[t]{2}{*}{ Cement } & 0 & 9 & 15.44 & 9.52 & \multirow{2}{*}{-0.630} & \multirow{2}{*}{0.534} \\
\hline & 1 & 18 & 17.96 & 9.92 & & \\
\hline \multirow[t]{2}{*}{ Multi-Investment } & 0 & 4 & 0.63 & 3.58 & \multirow{2}{*}{-0.526} & \multirow{2}{*}{0.605} \\
\hline & 1 & 17 & 1.60 & 3.29 & & \\
\hline \multicolumn{7}{|l|}{$X 4 \_3$} \\
\hline \multirow[t]{2}{*}{ Banking } & 0 & 16 & 9.40 & 8.30 & \multirow{2}{*}{-0.953} & \multirow{2}{*}{0.348} \\
\hline & 1 & 17 & 11.88 & 6.61 & & \\
\hline \multirow[t]{2}{*}{ Cement } & 0 & 15 & 15.71 & 9.95 & \multirow{2}{*}{-0.840} & \multirow{2}{*}{0.409} \\
\hline & 1 & 12 & 18.88 & 9.46 & & \\
\hline \multirow[t]{2}{*}{ Multi-Investment } & 0 & 13 & 1.63 & 3.21 & \multirow{2}{*}{0.361} & \multirow{2}{*}{0.722} \\
\hline & 1 & 8 & 1.08 & 3.57 & & \\
\hline \multicolumn{7}{|l|}{$X 4 \_4$} \\
\hline \multirow[t]{2}{*}{ Banking } & 0 & 24 & 9.74 & 8.17 & \multirow{2}{*}{$1.19-$} & \multirow{2}{*}{0.243} \\
\hline & 1 & 9 & 13.19 & 4.62 & & \\
\hline \multirow[t]{2}{*}{ Cement } & 0 & 15 & 15.71 & 9.48 & \multirow{2}{*}{$0.840-$} & \multirow{2}{*}{0.409} \\
\hline & 1 & 12 & 18.88 & 9.46 & & \\
\hline \multirow[t]{2}{*}{ Multi-Investment } & 0 & 18 & 1.03 & 3.38 & \multirow{2}{*}{ 3.234- } & \multirow{2}{*}{0.004} \\
\hline & 1 & 3 & 3.78 & 0.51 & & \\
\hline \multicolumn{7}{|l|}{$X 4 \_5$} \\
\hline \multirow[t]{2}{*}{ Banking } & 0 & 18 & 8.20 & 6.79 & \multirow{2}{*}{$2.215-$} & \\
\hline & 1 & 15 & 13.66 & 7.35 & & 0.004 \\
\hline Cement & 0 & 9 & 16.01 & 9.68 & 0412 & 0692 \\
\hline & 1 & 18 & 17.67 & 9.92 & $0.415^{-}$ & 0.003 \\
\hline Multi-Investment & 0 & 15 & 1.24 & 3.82 & 0380 & 0708 \\
\hline & 1 & 6 & 1.85 & 1.27 & $0.380-$ & 0.108 \\
\hline
\end{tabular}

Based on the information provided in table 18, it could be concluded that there is a significant effect of the disclosure of the discussion of corporate strategy; plans of investment in the coming years and participation in social responsibility on Return on Equity in the banking sector. While disclosing the company's market share showed a significant effect on ROE in Multi-Investment companies. Based on the above discussion $\mathrm{H} 8$ is failed to reject.

6.9 Testing H9: The Relationship between the ROA Ratio and the Board of Directors' Disclosed Information Differs Significantly among the Different Sectors

A study of the relationship between ROA and the disclosure of board of directors' information on the financial report represented in the variables $\left(X 2 \_1, X 2 \_2, X 2 \_3, X 2 \_4, X 2 \_5\right)$ for each sector is performed. The correlation between them is measured by Pearson Correlation Coefficient. 
Table 19. Correlation coefficient between ROA ratio and board of directors' disclosed information for each sector correlation

\begin{tabular}{|c|c|c|c|c|c|c|c|}
\hline Sector & & & $\mathrm{X} 2 \_1$ & $\mathrm{X} 2 \_2$ & $\mathrm{X} 2 \_3$ & $X 2 \_4$ & $\mathrm{X} 2 \_5$ \\
\hline \multirow[t]{3}{*}{ Banking } & ROA & Pearson Correlation & $.467^{*}$ & .077 & $.446^{*}$ & $-.452 * *$ & -.230 \\
\hline & & Sig. (2-tailed) & .012 & .672 & .017 & .009 & .214 \\
\hline & & $\mathrm{N}$ & 28 & 33 & 28 & 32 & 31 \\
\hline \multirow[t]{3}{*}{ Cement } & ROA & Pearson Correlation & .261 & .126 & $.506^{* *}$ & -.196 & .027 \\
\hline & & Sig. (2-tailed) & .198 & .540 & .008 & .347 & .894 \\
\hline & & $\mathrm{N}$ & 26 & 26 & 26 & 25 & 26 \\
\hline \multirow[t]{3}{*}{ Multi-Investment } & ROA & Pearson Correlation & -.282 & -.298 & -.119 & .251 & -.044 \\
\hline & & Sig. (2-tailed) & .216 & .189 & .606 & .330 & .861 \\
\hline & & $\mathrm{N}$ & 21 & 21 & 21 & 17 & 18 \\
\hline
\end{tabular}

**. Correlation is significant at the 0.01 level (2-tailed).

*. Correlation is significant at the 0.05 level (2-tailed).

Based on the results presented in table 19 it could be deduced that the number of board meetings and the percentage of board members attending the board meetings is positively correlated with ROA in the banking sector. However, there is a negative correlation between the number of independent members and ROA in such a sector. This could return that the banks in Saudi Arabia are controlled by major shareholders (sometimes family members) who don't prefer to allow independent board members to join their boards.

In the Cement sector, there is a positive correlation between the percentage of board members attending the board meetings and ROA. While in the Multi-Investment sector, there were no correlation between such information and ROA. Based on the above analysis, H9 is failed to reject.

6.10 Testing H10: The Relationship between the ROA Ratio and the Disclosure of Capital Structure Information Differs Significantly among the Different Sector

Pearson correlation coefficient is used to test the relationship between Y3 (Return on Assets) and the disclosure of capital structure information represented in the variables $\left(\mathrm{X} 1 \_1, \mathrm{X} 1 \_2, \mathrm{X} 1 \_3, \mathrm{X} 1 \_4\right)$ for each sector.

Table 20. Correlation coefficient between ROA ratio and the disclosure of capital structure information of each sector

\begin{tabular}{|c|c|c|c|c|c|c|}
\hline Sector & & & X1_1 & $\mathrm{X} 1 \_2$ & X1_3 & $\mathrm{X} 1 \_4$ \\
\hline \multirow[t]{3}{*}{ Banking } & ROA & Pearson Correlation & .196 & .130 & .282 & -.001 \\
\hline & & Sig. (2-tailed) & .275 & .472 & .111 & .994 \\
\hline & & $\mathrm{N}$ & 33 & 33 & 33 & 33 \\
\hline \multirow[t]{3}{*}{ Cement } & ROA & Pearson Correlation & -.128 & $.587^{* *}$ & $.647 * *$ & -.011 \\
\hline & & Sig. (2-tailed) & .523 & .001 & .000 & .958 \\
\hline & & $\mathrm{N}$ & 27 & 27 & 27 & 27 \\
\hline \multirow[t]{3}{*}{ Multi-Investment } & ROA & Pearson Correlation & .296 & .030 & .191 &. $\mathrm{a}$ \\
\hline & & Sig. (2-tailed) & .192 & .897 & .408 & . \\
\hline & & $\mathrm{N}$ & 21 & 21 & 21 & 21 \\
\hline
\end{tabular}

\footnotetext{
** Correlation is significant at the 0.01 level (2-tailed).

a. Cannot be computed because at least one of the variables is constant.
} 
Based on the results presented in table 20, it could be concluded that the Cement sector is the only sector that has a positive correlation between ROA and both the disclosure of capital structure and the percentage of management shareholding information. The other two sectors do not show any correlation between ROA and the capital structure variables. These results confirm the results of another study (Al-Hussain \& Johnson, 2009) applied on Saudi Arabian banks. Based on the above analysis, H10 is failed to reject.

6.11 Testing H11: The Effect of the Disclosure of Financial Information on ROA Ratio Differs Significantly among the Different Sectors

To test this hypothesis, the relationship between Y3 (ROA ratio) and the disclosure of financial variables (X3_1, X3_2, X3_3, X3_4) for each sector is investigated. As the disclosure of financial information variables took the binary form where "1" (present) and "0" (absent), hence, the two independent samples T-Test has been used to study such relationship.

Table 21. T-test to plot the relationship between ROA ratio and disclosure of financial information variables

\begin{tabular}{|c|c|c|c|c|c|c|}
\hline sector & Variable Values & No. of values & Mean & St. Dev. & T-Test & Sig. \\
\hline \multicolumn{7}{|l|}{$X 3 \_1$} \\
\hline \multirow[t]{2}{*}{ Banking } & 0 & 8 & 1.97 & 0.97 & 1.044 & 0.305 \\
\hline & 1 & 25 & 1.48 & 1.18 & & \\
\hline \multirow[t]{2}{*}{ Cement } & 0 & 7 & 10.32 & 6.36 & -1.326 & 0.197 \\
\hline & 1 & 20 & 15.31 & 9.18 & & \\
\hline \multirow[t]{2}{*}{ Multi-Investment } & 0 & 0 & - & - & - & - \\
\hline & 1 & 21 & 1.08 & 2.63 & & \\
\hline \multicolumn{7}{|l|}{$X 3 \_2$} \\
\hline \multirow[t]{2}{*}{ Banking } & 0 & 10 & 2.27 & 1.08 & 2.398 & 0.023 \\
\hline & 1 & 23 & 1.31 & 1.05 & & \\
\hline \multirow[t]{2}{*}{ Cement } & 0 & 9 & 8.63 & 6.51 & -2.941 & 0.020 \\
\hline & 1 & 18 & 16.71 & 8.55 & & \\
\hline \multirow[t]{2}{*}{ Multi-Investment } & 0 & 6 & 2.15 & 1.58 & 1.200 & 0.245 \\
\hline & 1 & 15 & 0.65 & 2.87 & & \\
\hline \multicolumn{7}{|l|}{$X 3 \_3$} \\
\hline \multirow[t]{2}{*}{ Banking } & 0 & 1 & 3.96 & - & 2.236 & 0.033 \\
\hline & 1 & 32 & 1.53 & 1.07 & & \\
\hline \multirow[t]{2}{*}{ Cement } & 0 & 9 & 8.63 & 6.51 & -2.491 & 0.020 \\
\hline & 1 & 18 & 16.71 & 8.55 & & \\
\hline \multirow[t]{2}{*}{ Multi-Investment } & 0 & 6 & 2.15 & 1.58 & 1.200 & 0.245 \\
\hline & 1 & 15 & 0.65 & 2.87 & & \\
\hline \multicolumn{7}{|l|}{$X 3 \_4$} \\
\hline \multirow[t]{2}{*}{ Banking } & 0 & 16 & 2.08 & 1.01 & 2.505 & 0.018 \\
\hline & 1 & 17 & 1.16 & 1.09 & & \\
\hline \multirow[t]{2}{*}{ Cement } & 0 & 27 & 14.02 & 8.71 & - & - \\
\hline & 1 & 0 & - & - & & \\
\hline \multirow[t]{2}{*}{ Multi-Investment } & 0 & 18 & 0.83 & 2.76 & -2.552 & 0.020 \\
\hline & 1 & 3 & 2.56 & 0.32 & & \\
\hline
\end{tabular}

Based on the analysis provided in table 21, it could be concluded that disclosing basic earnings forecasts did not show any significant effect on ROA. However, disclosing the segment analysis showed a significant effect on ROA in the Cement sector, while concealing such information had a significant effect on the ROA in the banking sector. Disclosing analysis of the revenue structure shows a significant effect on ROA in the Cement industry. Disclosing of analysis of cost structure showed a significant effect on ROA in the Multi-Investment sector, while concealing such information had an effect on ROA in the banking sector. Hence, H11 is failed to reject. 
6.12 Testing H12: The Effect of the Disclosure of Operational Information on ROA Ratio Differs Significantly among the Different Sectors

The relationship between Y3 (ROA) and the disclosure of operational information variables (X4_1, X4_2, X4_3, $\mathrm{X} 4 \_4, \mathrm{X} 4 \_5$ ) for each sector is investigated. As the disclosure of the operational information variables took the binary form where " 1 " (present) and " 0 " (absent), hence, the two independent samples T-Test has been used to study such relationship.

Table 22. T-Test to plot the relationship between ROA ratio and disclosure of operational information variables

\begin{tabular}{|c|c|c|c|c|c|c|}
\hline sector & Variable Values & No. of values & Mean & St. Dev. & T-Test & Sig. \\
\hline \multicolumn{7}{|l|}{$X 4 \_1$} \\
\hline \multirow[t]{2}{*}{ Banking } & 0 & 3 & 1.08 & 0.27 & -2.183 & 0.047 \\
\hline & 1 & 30 & 1.65 & 1.18 & & \\
\hline \multirow[t]{2}{*}{ Cement } & 0 & 7 & 15.19 & 11.63 & 0.408 & 0.687 \\
\hline & 1 & 20 & 13.61 & 7.77 & & \\
\hline \multirow[t]{2}{*}{ Multi-Investment } & 0 & 1 & -3.56 & - & -1.928 & 0.069 \\
\hline & 1 & 20 & 1.31 & 2.46 & & \\
\hline \multicolumn{7}{|l|}{$X 4 \_2$} \\
\hline \multirow[t]{2}{*}{ Banking } & 0 & 6 & 0.57 & 1.03 & -2.683 & 0.012 \\
\hline & 1 & 27 & 1.83 & 1.04 & & \\
\hline \multirow[t]{2}{*}{ Cement } & 0 & 9 & 13.52 & 8.44 & -0.208 & 0.837 \\
\hline & 1 & 18 & 14.27 & 9.07 & & \\
\hline \multirow[t]{2}{*}{ Multi-Investment } & 0 & 4 & 0.81 & 3.09 & -0.223 & 0.826 \\
\hline & 1 & 17 & 1.14 & 2.61 & & \\
\hline \multicolumn{7}{|l|}{$X 4 \_3$} \\
\hline \multirow[t]{2}{*}{ Banking } & 0 & 16 & 1.66 & 1.30 & -0.241 & 0.811 \\
\hline & 1 & 17 & 1.65 & 0.99 & & \\
\hline \multirow[t]{2}{*}{ Cement } & 0 & 15 & 13.08 & 8.87 & -0.619 & 0.542 \\
\hline & 1 & 12 & 15.19 & 8.75 & & \\
\hline \multirow[t]{2}{*}{ Multi-Investment } & 0 & 13 & 1.38 & 2.65 & 0.676 & 0.507 \\
\hline & 1 & 8 & 0.58 & 2.69 & & \\
\hline \multicolumn{7}{|l|}{$X 4 \_4$} \\
\hline \multirow[t]{2}{*}{ Banking } & 0 & 24 & 1.58 & 1.29 & -0.191 & 0.850 \\
\hline & 1 & 9 & 1.66 & 0.64 & & \\
\hline \multirow[t]{2}{*}{ Cement } & 0 & 15 & 13.08 & 8.87 & -0.619 & 0.542 \\
\hline & 1 & 12 & 15.19 & 8.75 & & \\
\hline \multirow[t]{2}{*}{ Multi-Investment } & 0 & 18 & 0.83 & 2.76 & -2.252 & 0.020 \\
\hline & 1 & 3 & 2.56 & 0.32 & & \\
\hline \multicolumn{7}{|l|}{$X 4 \_5$} \\
\hline \multirow[t]{2}{*}{ Banking } & 0 & 18 & 1.31 & 1.08 & -1.650 & 0.109 \\
\hline & 1 & 15 & 1.95 & 1.14 & & \\
\hline \multirow[t]{2}{*}{ Cement } & 0 & 9 & 12.84 & 8.53 & -0.489 & 0.629 \\
\hline & 1 & 18 & 14.61 & 8.98 & & \\
\hline \multirow[t]{2}{*}{ Multi-Investment } & 0 & 15 & 0.89 & 3.03 & -0.496 & 0.826 \\
\hline & 1 & 6 & 1.53 & 1.24 & & \\
\hline
\end{tabular}


Based on the information provided in table 22, it could be concluded that disclosing the discussion of corporate strategy; an overview of the industry and participation in social responsibilities had no significant effect on ROA in all of the three sectors. However, disclosing plans of investments in the future had a significant effect on ROA in the banking sector and disclosing the company's market share had a significant effect on ROA in the Multi-Investment sector. Hence, $\mathrm{H} 12$ is failed to reject.

\section{Conclusions and Comments}

Based on the above statistical analysis and testing of hypotheses, the following could be concluded regarding each sector as follows:

\subsection{The Banking Sector}

It appears that there is a significant effect of the information disclosed on the performance measures (ROE \& ROA). There is a positive correlation of the percent of attending board meetings on both ROE \& ROA. There is a positive correlation between the number of board of directors and ROA. However, there is a negative correlation between the number of the independent board members and both ROE \& ROA. This could return to the particular case of the Saudi banks where many of them are owned by families, or major institutions. On the other hand side, There is a significant positive effect of concealing cost structure and segment analysis on both ROE \& ROA. This result needs more research to understand the rationale behind it. It is found that there is a significant positive effect of disclosing the future plans on both ROE \& ROA. However, disclosing the discussion of corporate strategy and social responsibility had a significant positive effect on ROE, while disclosing the market share has a significant positive effect on ROA. This confirms the results achieved by (Nuryaman, 2012) as it was found that the practice of corporate governance has a positive effect on company's performance. It was also found that the market measure (PE) is positively correlated with disclosing the bank's capital structure. No other disclosure affects the PE ratio regarding the banking sector.

\subsection{The Cement Sector}

Some disclosure is significantly positively correlated with performance as measured by ROE \& ROA. The percentage of attending board of directors' meetings is positively correlated with ROA and ROE. Also, disclosing both segment analysis where results are broken down by business line and revenue structure have a significant positive effect on ROE \& ROA. The capital structure and the percentage of management shareholding are positively correlated to ROE. The executive compensation is positively correlated to PE.

\subsection{Multi-Investment Sector}

There is a significant effect disclosing the cost structure on ROE \& ROA. Also, revealing the company's market share has a significant positive effect on ROE. As for PE, it is found that there is a significant effect of disclosing an overview of the industry trend and a company's market share.

It is clear from the previous study that the relationship of disclosure on annual reports is different from one sector to the other. This result confirms a study by (Larcker, Richardson, \& Tuna, 2007). The effect of such disclosure on the PE ratio is minimal, and the effect on a company's performance varies according to each sector. Based on the above analysis, it seems that not all of the disclosure criteria as announced by the corporate governance regulation do not necessarily affect companies' performance. Stock market authorities in Saudi Arabia need to rethink the content and details of the disclosure in annual reports that would benefit current and future investors. More research is needed to identify the disclosure that have an effect on a company's performance.

\section{References}

Abed, S., Al-Okdeh, S., \& Nimer, K. (2011). The inclusion of forecasts in the narrative sections of annual reports and their association with firm characteristics: The case of Jordan. International Business Research, 4(4), 264-271. http://dx.doi.org/10.5539/ibr.v4n4p264

Adiloglu, B., \& Vuran, B. (2012). The relationship between the financial ratios and transparency levels of financial information disclosures within the scope of corporate governance: Evidence from turkey. Journal of Applied Business Research, 28(4), 543-554.

Al-Hussain, A. H., \& Johnson, R. L. (2009). Relationship between corporate governance efficiency and Saudi banks' performance. The Business Review, Cambridge, 14(1), 111-117.

Aluchna, M. (2009). Does good corporate governance matter? Best practice in Poland. Management Research News, 32(2), 185-198. http://dx.doi.org.ezproxy.macewan.ca/10.1108/01409170910927631 
Bhagat, S., \& Bolton, B. (september 2006). Board ownership and corporate governance indices. Unpublished University of Colorado at Boulder.

Brown, L. D., \& Caylor, M. L. (2009). Corporate governance and firm operating performance. Review of Quantitative Finance and Accounting, 32(2), 129-144. http://dx.doi.org/10.1007/s11156-007-0082-3

Christiansen, H., \& Koldertsova, A. (2009). The role of stock exchanges in corporate governance. OECD Journal.Financial Market Trends, (1), 209-238. http://dx.doi.org/10.1787/fmt-v2009-art10-en

Donker, H., Poff, D., \& Zahir, S. (2008). Corporate values, codes of ethics, and firm performance: A look at the canadian context. Journal of Business Ethics, 82(3), 527-537. http://dx.doi.org/10.1007/s10551-007-9579-x

Foerster, S. R., \& Huen, B. C. (2004). Does corporate governance matter to Canadian investors? Canadian Investment Review, 17(3), 19-26.

Fong, S. C. C., \& Shek, W. W. Y. (2009). Corporate governance disclosure and company performance of Hong Kong-based and China-based family-controlled property development companies. IUP Journal of Corporate Governance, 8(3/4), 7-50.

Gropp, R., \& Köhler, M. (2010). Bank owners or bank managers: Who is keen on risk? Evidence from the financial crisis. Rochester, Rochester: Social Science Research Network. http://dx.doi.org.ezproxy.macewan.ca/10.2139/ssrn.1569250

Hua, C. (2003). Corporate governance, board compensation and firm performance: An investigation of corporate governance in Taiwan's high-tech industry. D.B.A., Golden Gate University.

Kaur, P., \& Gill, S. (2009). Patterns of corporate ownership: Evidence from BSE-200 index companies. Paradigm, 13(2), 13-28.

Larcker, D. F., Richardson, S. A., \& Tuna, I. (2007). Corporate governance, accounting outcomes, and organizational performance. The Accounting Review, 82(4), 963-1008. http://dx.doi.org/10.2308/accr.2007.82.4.963

Mohd Hassan, C. H., Rashidah, A. R., \& Mahenthiran, S. (2008). Corporate governance, transparency and performance of Malaysian companies. Managerial Auditing Journal, 23(8), 744-778. http://dx.doi.org/10.1108/02686900810899518

Nuryaman, N. (2012). The influence of corporate governance practices on the company's financial performance: studies on the companies surveyed by IICG and listed on the Indonesia stock exchange. Journal of Global Business and Economics, 5(1)

S\&P/Hawkamah ESG Pan Arab index methodology. (2013). S\&P Dow Jones Indices: McGraw-Hill Financials.

Xiaonian X., \& Yan. W. (1999). Ownership structure and corporate governance in Chinese stock companies. China Economic Review, 10, 75-98. http://dx.doi.org/10.1016/S1043-951X(99)00006-1

\section{Note}

Note 1. A detailed list of the companies included in each sector is present in the appendix.

\section{Appendix}

Appendix 1. List of companies

\begin{tabular}{lll}
\hline sector & \multicolumn{2}{l}{ Company's Name } \\
\hline Banking: & $1-\quad$ Riyad Bank. \\
& $2-\quad$ Bank AlJazira \\
& $3-$ & The Saudi Investment Bank \\
& $4-$ & Saudi Hollandi Bank \\
& $5-$ & Banque Saudi Fransi \\
& $6-$ & The Saudi British Bank \\
& $7-$ & Arab National Bank \\
& $8-$ & Samba Financial Corporation. \\
$9-$ & Al Rajhi Bank \\
$10-$ & Bank Albilad \\
$11-$ & Alinma Bank \\
\hline
\end{tabular}




\begin{tabular}{lll}
\hline Cement: & $1-$ & Arabian Cement Company \\
$2-$ & Yamamah Saudi Cement Company \\
$3-$ & Saudi Cement Company \\
$4-$ & The Qassim Cement Company \\
$5-$ & Southern Province Cement Company \\
$6-$ & Yanbu Cement Company \\
$7-$ & Eastern Province Cement Company \\
& $8-\quad$ Tabuk Cement Company. \\
& $9-\quad$ Al Jouf Cement Company \\
& $1-\quad$ Saudi Arabia Refineries Company \\
Multi-Investment & $2-\quad$ Saudi Advance Industries Company \\
& $3-\quad$ Al-Ahsa Development Company \\
$4-$ & Saudi Industrial services Company \\
$5-$ & Aseer Trading, Tourism \& Manufacturing Co. \\
$6-$ & Al-Baha Investment \& Development Co. \\
$7-$ & Kingdom Holding Company
\end{tabular}

\section{Copyrights}

Copyright for this article is retained by the author(s), with first publication rights granted to the journal.

This is an open-access article distributed under the terms and conditions of the Creative Commons Attribution license (http://creativecommons.org/licenses/by/3.0/). 